\title{
Anti-inflammatory Modulating Effect of Rengyolone in Rat
}

\author{
Gil-Hyon Lee ${ }^{1, *}$, Kyung-Yae Hyun ${ }^{3, *}$ and Yoon-Jung Kang ${ }^{2, \dagger ; *}$ \\ ${ }^{1}$ Department of Clinical Laboratory Science, Dong-seo University, Busan 47011, Korea \\ ${ }^{2}$ Department of Clinical Laboratory Science, Sang-ji University, Wonju 26339, Korea \\ ${ }^{3}$ Department of Clinical Laboratory Science, Dong-eui University, Busan 47340, Korea
}

\begin{abstract}
Hepatitis refers to inflammation of hepatocytes and liver tissue, and is mainly caused by viruses, alcohol, and drugs. Forsythiae Fructus has traditionally been used as a diuretic, anti-inflammatory and antipyretic. Research on rengyolone, a bioactive substance extracted from Forsythiae Fructus, is rarely found in Korea and abroad. First, an acute animal toxicity test for rengyolone was conducted for the animal experiment. 4 week-old SD rats were injected intraperitoneally with acetaminophen for 2 weeks to induce chronic liver inflammation. Rengyolone was orally administered into two groups during 4 weeks: pre-inflammatory group and post-inflammatory group. Oral doses were also divided into $1 \mathrm{mg} / \mathrm{kg}$ and $5 \mathrm{mg} / \mathrm{kg}$. Liver function tests (ALT, AST, ALP), western blot analysis of liver tissue, and level of inflammatory cytokine were performed to evaluate the improvement of hepatitis. Experimental results showed that rengyolone inhibited the development of acute inflammation and thus could reduce hepatitis symptoms.
\end{abstract}

Key Words: Hepatitis, Forsythiae fructus, Rengyolone, Acetaminophen, Liver function tests, iNOS

\section{서 론}

간염(hepatitis)은 간세포의 손상을 말하며 우리나라에서 는 간염은 흔한 질환 중에 하나이다. 간염은 통상 바이러 스에 의하여 발생한다고 알려져 있으나 알코올과 같은 독성물질에 의하여 발생하는 간염도 있다(Tian et al., 2018). 6개월 이상 지속되는 만성간염인 경우 적절한 치료 가 병행되지 않으면 심각한 간손상인 간경변으로 진행된 다(Lightsey and Rockey, 2017; Pérez-Gracia et al., 2017). 간염 의 이유(바이러스, 지방, 자가면역, 독성물질 등)에 대한 근원적인 치료가 간염의 치료에 핵심이지만 항진된 염증 상태에 있는 간조직에 대한 염증발현 저하를 위한 처치는 간염 치료를 위하여 필요하다고 알려져 있다(Kanzler et al.,
2007). 간기능검사(liver function tests, LFT)는 asparate aminotransferase (AST), alanine aminotransferase (ALT), alkaline phosphatase (ALP), 알부민(albumin), 빌리루빈(bilirubin)의 수치를 평가하는 검사이다. 간기능검사는 간담도계질환 선별에 효과적이며 감별진단의 방향을 제시한다(Kanzler et al., 2007). 간손상이 심해지면 AST, ALT가 상승하며 특 히 간경화증에서는 AST/ALT 비가 상승한다고 알려져 있 다(Thapa and Walia, 2017; Gressner et al., 2007). ALP는 모든 종류의 간질환에서 상승하며 종양에 의한 침윤성 간염에 서 현저히 증가한다. 이들 간기능검사의 항목의 변화는 간질환 선별에 효과적이며 간질환의 중증도와 치료반응 평가에 유용하다(Gressner et al., 2007). 만성적인 염증상태 에 있는 만성간염환자는 혈장에서 염증성 사이토카인(proinflammatory cytokine) Tumor necrosis factor-alpha (TNF- $\alpha$ ),

Received: February 26, 2019 / Revised: March 26, 2019 / Accepted: March 27, 2019

* Professor.

†Corresponding author: Yoon-Jung Kang. Department of Clinical Laboratory Science, Sang-ji University, 83 Sangjidaegil, Seo-gu, Wonju 26339, Korea. Tel: +82-33-738-8081, Fax: +82-33-730-0114, e-mail: lvpig@naver.com

(C) The Korean Society for Biomedical Laboratory Sciences. All rights reserved.

(c) This is an Open Access article distributed under the terms of the Creative Commons Attribution Non-Commercial License (http://creativecommons.org/licenses/by-nc/3.0/) which permits unrestricted non-commercial use, distribution, and reproduction in any medium, provided the original work is properly cited. 


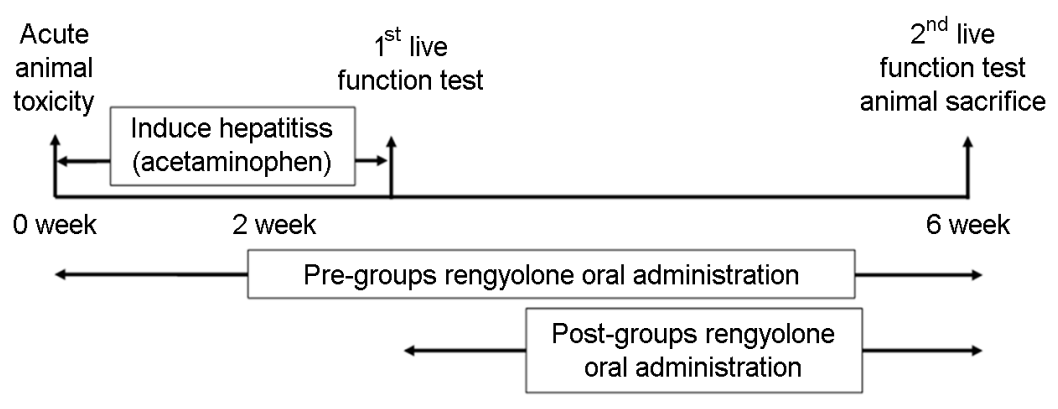

Fig. 1. Experimental schedule. Acute hepatitis was induced for 2 weeks and then rengyolone was given orally for 4 weeks. Animals were sacrificed after 6 weeks of animal experiment and samples were collected.
Interleukin-6 (IL-6) 등이 증가되어 있으며 이러한 사이토카 인에 의하여 inducible NOS (iNOS) 발현이 증가되며 iNOS 에 의하여 NO가 다수 방출된다(Brown, 2008; Mariotto et al., 2007). 따라서 염증상태가 호전되면 사이토카인의 양이 감 소되며 iNOS, NO의 발현도 저하된다. 실험에서 만성염증 상태가 호전된다면 이들 인자들의 발현도 자연스럽게 저 하될 것이라 예상된다.

연교(Forsythiae Fructus)는 의성개나리(Forsythia viridissima Lindley) 또는 연교(Forsythia suspensa Vahl)라고 불리는 물 푸레나무과의 열매이다. 연교는 전통적으로 이뇨제, 항염 증제, 해열제로 전통적으로 사용되어 왔으며 연구에 의하 며 항산화(Debnath et al., 2013), 항균(Qu et al., 2008), 항바이 러스(Law et al., 2017) 등의 효과가 있다고 알려져 있다. 그 러나 현재 연교의 생리활성물질에 대한 연구는 거의 진행 되어 있지 않으며 그 중 rengyolone에 대한 연구는 전무 한 실정이다. 본 연구는 연교의 구성성분인 rengyolone을 만성염증상태인 간염동물모델에 경구투여함으로 실험동 물에서 rengyolone 항염증효과 및 간염증 감소효과를 조 사하였다.

\section{재료 및 방법}

\section{실험동물}

4주령 Sprague Dawley (SD) rat을 중앙동물센터(대전, 한 국)에서 암컷 60마리 구입하였으며 멸균된 cage에서 2일 간 안정시기를 갖게 하였다. 동물은 습도 $70 \pm 10 \%$, 온도 $20 \pm 5^{\circ} \mathrm{C}$ 를 유지하였으며 먹이를 충분히 공급하였다. 본 연구는 동의대학교 동물윤리심의를 준수하여 시행하였다.

\section{실험계획 및 실험군 분류}

동물 안정 이후 2 주에 걸쳐 간염을 유발하였으며 rengyolone의 아세트아미노펜(acetaminophen)로 유발되는 간독
성에 대한 보호효과를 확인하기 위한 간염유발 전 투여군 과 치료효과를 확인하기 위한 간염유발 후 투여군으로 설 정하였다(Fig. 1). 간염증 유발 전 동물군과 유발 후 동물 군으로 분리하여 실행하였으며 rengyolone의 투여 농도 또한 $5 \mathrm{mg} / \mathrm{kg}$ and $1 \mathrm{mg} / \mathrm{kg}$ 으로 나누어 경구투여하였다. 간 염유발 시작 6주 후 동물을 희생하였으며 동물의 혈액을 채취하고 원심분리하여 혈장을 수집하였다. 또한 간조직 을 재취하였다. 본 연구에서 실험군은 각 군 10 마리씩 다 음과 같이 분류하였다. Sham: 정상군+생리식염수 투여군, Hepatitis-induced Group: 간염증 유발+생리식염수 투여, Prelow: 간염증 유발+간염유발 전 6주 동안 저농도약물투여 $(1 \mathrm{mg} / \mathrm{kg})$, Pre-high: 간염증 유발+간염증 유발 전 6주 동 안 고농도약물투여 $(5 \mathrm{mg} / \mathrm{kg})$, Post-low: 간염증 유발+간염 증 유발 후 4주 동안 저농도약물투여 $(1 \mathrm{mg} / \mathrm{kg})$, Post-high: 간염증 유발+간염증 유발 후 4주 동안 고농도약물투여 $(5 \mathrm{mg} / \mathrm{kg})$, Positive control: 간염증 유발+4주간 Vitamine C, $\mathrm{E}$ 복합제 $(1 \mathrm{mg} / \mathrm{kg})$. 항산화제는 간염을 일으키는 산화스트 레스를 감소시키고 염증성 cytokine을 줄여서 간염의 치료 에 사용되어 왔으며 대표적인 항산화제로는 비타민 $\mathrm{E}$, 비 타민 C, 베타인(betaine) 등이 있다. 이에 본 연구에서 비 타민 C, E 복합제를 positive control로 선정하였다.

\section{급성독성시험}

체중 $100 \sim 120 \mathrm{~g}$ 의 SD rat을 대상으로 농도별로 3마리 의 동물군에 rengyolone을 경구투여하였다. Rengyolone을 $2,000 \mathrm{mg} / \mathrm{kg}, 3,000 \mathrm{mg} / \mathrm{kg}$ 용량으로 경구투여 후 이틀 동안 행동변화, 체중변화, 임상증상 및 사망을 관찰하였으며 실 험기간 중 사망 및 관찰기간 종료 후 생존한 동물군 모 두 전부 부검하여 장기이상여부를 관찰하였다.

\section{간염유발 및 간기능검사}

간염유발은 Park의 방법(Park and Jeong, 1995)을 수정하 
Table 1. Results of liver function test

(A) 1st liver function test

\begin{tabular}{lccccc}
\hline \hline & \multicolumn{4}{c}{ Experimental groups } \\
\cline { 2 - 6 } Variables & Sham & $\begin{array}{c}\text { Hepatitis-induced } \\
\text { group }\end{array}$ & Post-low & \multirow{2}{*}{ Post-high } & \multirow{2}{*}{ Positive control } \\
\cline { 2 - 6 } AST (IU/L) & $144.25 \pm 14.51^{*}$ & $381.41 \pm 11.89$ & $355.20 \pm 12.65$ & $355.87 \pm 17.61$ & $373.28 \pm 12.08$ \\
ALT (IU/L) & $7.25 \pm 1.31^{*}$ & $28.71 \pm 0.89$ & $29.89 \pm 0.79$ & $29.12 \pm 1.59$ & $30.51 \pm 1.62$ \\
ALP (IU/L) & $240.75 \pm 10.50^{*}$ & $378.10 \pm 12.69$ & $351.19 \pm 13.40$ & $337.05 \pm 11.89$ & $329.02 \pm 10.88$ \\
\hline
\end{tabular}

(B) 2nd liver function test

\begin{tabular}{lccccc}
\hline \hline & \multicolumn{3}{c}{ Experimental groups } \\
\cline { 2 - 6 } Variables & Sham & Hepatitis-induced & Post-low & Post-high & \multirow{2}{*}{ Positive control } \\
\cline { 2 - 6 } & $139.70 \pm 9.80$ & $261.10 \pm 9.85$ & $158.78 \pm 7.88^{\wedge}$ & $178.04 \pm 12.60^{\wedge}$ & $161.80 \pm 10.01^{\wedge}$ \\
AST (IU/L) & $7.99 \pm 1.10$ & $20.05 \pm 1.95$ & $12.88 \pm 3.46^{\wedge}$ & $10.50 \pm 2.51^{\wedge}$ & $10.10 \pm 1.94^{\wedge}$ \\
ALP (IU/L) & $218.58 \pm 11.82$ & $278.50 \pm 21.54$ & $221.40 \pm 14.91^{\wedge}$ & $225.09 \pm 12.97^{\wedge}$ & $212.82 \pm 13.71^{\wedge}$ \\
\hline
\end{tabular}

Liver function tests were performed at 2 (Table 1A) and 6 (Table 1B) weeks according to schedule

A) There was a significant difference in the liver function markers in the Sham group compared to the hepatitis-induced groups (Hepatitisinduced group, Post-low, Post-high, Positive control) $(*, P<0.05)$

B) The results of the liver function tests performed 6 weeks later showed that the hepatic function values of the experimental groups (Post-low, Post-high, Positive control) were significantly lower than those of the hepatitis-induced group $\left({ }^{\wedge}, P<0.05\right)$. Abbreviation: AST, aspartate aminotransferase; ALT, alanine aminotransferase; ALP, alkaline phosphatase

여 실시하였다. 아세트아미노펜을 동물 몸무게에 따라 $1 \mathrm{mg} / \mathrm{kg}$ 농도로 하루에 두 번 2주 동안 복강투여하였으며 간염유발 유무룰 간기능검사를 통하여 검증하였다. 간기 능평가는 Hitachi clinical analyzer 7180 (Hitachi Ltd, Tokyo, Japan) 진단화학분석기를 이용하여 혈장에 존재하는 ALP, $\mathrm{AST}, \mathrm{ALP}$ 를 측정하였다.

\section{사이토카인 측정}

희생된 동물의 혈장에 존재하는 염증성 사이토카인 $\mathrm{IL}-6$ 와 TNF- $\alpha$ 의 농도를 측정하기 위하여 Quantikine ELISA kit (R\&D Ltd, Mineapolis, USA)를 사용하였으며 실험방법 은 manufacturer's instruction을 따랐다.

\section{Western blot}

적출한 간조직을 무균 수술용 칼로 잘게 다지고, lysis buffer를 첨가하여 $4{ }^{\circ} \mathrm{C}$ 에서 homogenizer를 이용하여 균질 화하였다. 이 후 각 군의 간조직을 같은 단백질 농도로 정량화하였다. 준비된 sample은 $10 \sim 12 \%$ gel에 $18.5 \mu \mathrm{L}$ 로 샘플을 loading 후 전기영동 하였다. 교반기에서 blocking buffer (1X PBST, skim milk, sodium azide)로 1시간씩, 2번의 새 blocking buffer로 교체하여 blocking하고 iNOS (Ab)를
$4{ }^{\circ} \mathrm{C}$ 에서 over night 시켰다. 7 분간 5 회에 걸쳐 $1 \mathrm{X}$ PBST (10X PBST, D.W, 0.1\% Tween 20)로 수세 후 2차 $\mathrm{Ab}$ 를 교 반기 위에서 2시간 실온 반응시키고 $\mathrm{ECL}$ 을 이용하여 발 현, 분석하였다. 영상분석은 Image J Software을 이용하여 발현 정도를 측정하였다.

\section{자료분석 및 통계처리}

모든 자료들은 가능한 평균값 \pm 표준편차로 표시하였 다. 실험군 사이의 정규성 검정을 실시하였으며 정규성이 있을 때 각 군 간의 모든 변수 비교는 $\operatorname{ANOVA(ㅂㅜㄴㅅㅏㄴㅂㅜㄴㅅㅓㄱ)~}$ 로 유의성을 검정 후 유의한 결과가 나올 때 Turkey 법으 로 사후검정을 적용하였다(SPSS program, Version 12.0).

\section{결 과}

\section{급성독성시험}

3마리 동물이 죽지 않았으며 이틀 후 해부 결과 장기 손상 및 변색현상이 없었다. 간기능검사 및 혈액분석 결 과 모두 정상치 범위 내였다(결과를 표 및 그림으로 표시 안함). 


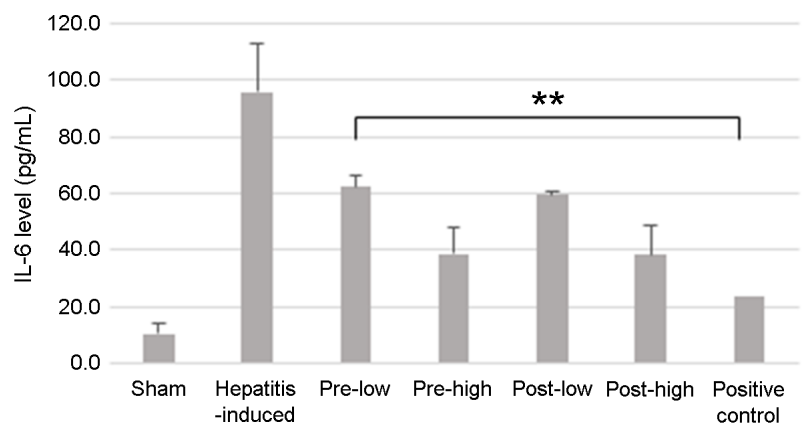

Fig. 2. Concentration of IL-6 in serum. The concentration of IL-6 tends to decrease in a concentration-dependent manner. There was a significant difference in the treatment groups compared to hepatitisinduced group $(* *, P<0.01)$.

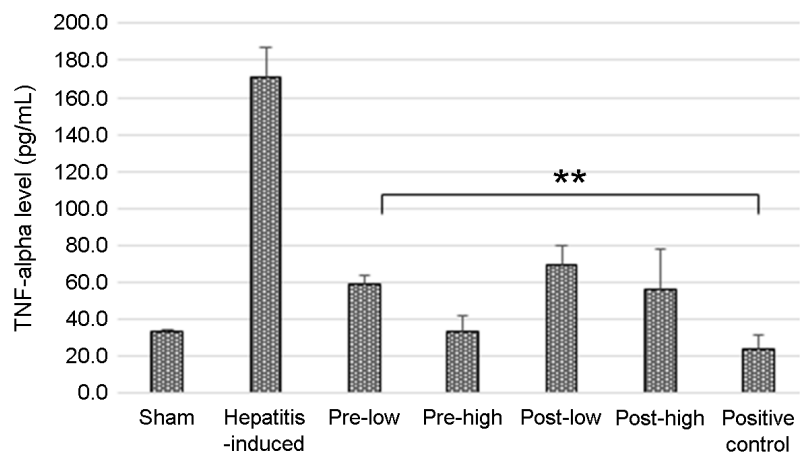

Fig. 3. Concentration of TNF- $\alpha$ in serum. The concentration of TNF- $\alpha$ was significantly increased in the hepatitis-induced group. There was a significant difference in the treatment groups compared to the hepatitis-induced group $(* *, P<0.01)$.

\section{간기능검사}

2주 차 간염증을 유발한 후 동물간염을 검증하기 위 하여 post-treatment 군을 대상으로 꼬리정맥에서 채혈한 혈액을 이용하여 간기능인자(ALT, ALP, AST)를 측정하였 다(Table 1A). 그리고 4주 동안 rengyolone 투여 후 동물 을 희생하고 채취한 혈액에서 간기능인자를 분석하였다 (Table 1B). Table 1A 결과를 보면 Sham 군을 제외한 모든 군들의 간기능인자의 수치가 현저하게 증가된 경향을 볼 수 있었다. Rengyolone의 4주 투입 후 간기능인자의 결과 는 Hepatitis-induced group을 제외한 물질투여군에서 간기 능인자의 결과가 호전되었음을 알 수 있었다(Table 1).

\section{사이토카인 농도}

Fig. 2 의 결과는 간조직에서의 IL-6의 발현을 보여주고 있다. Hepatitis-induced group에서 $95.7 \pm 17.2 \mathrm{pg} / \mathrm{mL}$ 로 고

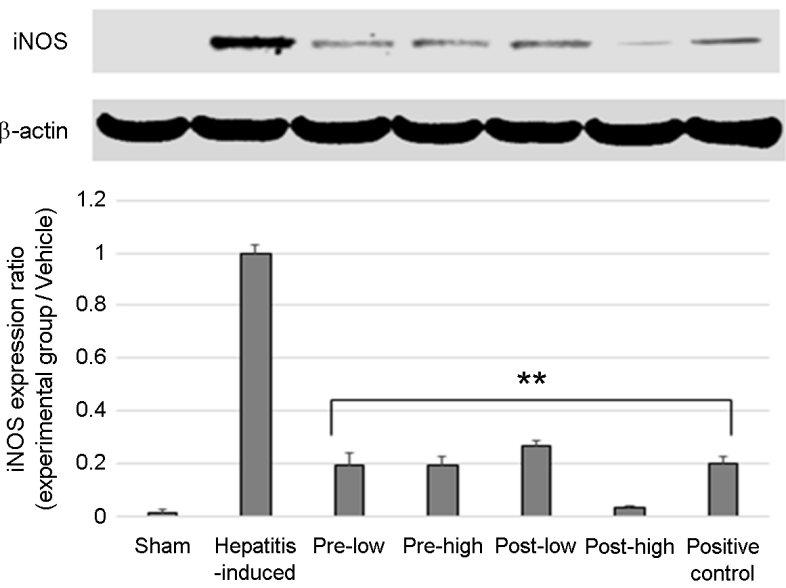

Fig. 4. Expression of iNOS in liver tissue. The protein concentration of iNOS was significantly increased in the hepatitis-induced group. There was a significant difference in the treatment groups compared to the hepatitis-induced group $(* *, P<0.01)$.

농도 발현을 보였지만 나머지 실험군에서는 통계적으로 유의한 차이를 보이며 저하된 경향을 볼 수 있었다 $(P<$ 0.01). 간조직에서의 TNF- $\alpha$ 의 농도변화를 Fig. 3 에서 보 여주고 있다. TNF- $\alpha$ 는 정상군에서는 $33.2 \pm 0.9 \mathrm{pg} / \mathrm{mL}$ 의 농도인 반면 Hepatitis-induced group에서는 $171.3 \pm$ $11.2 \mathrm{pg} / \mathrm{mL}$ 로 확연히 증가되었음을 알 수 있었다. 그러나 Hepatitis-induced group에 비하여 나머지 실험군에서는 통 계적으로 유의한 차이를 보이며 저하된 경향을 볼 수 있 었다 $(P<0.01)$. Pre-treatment 군과 post-treatment 군을 비교 해 볼 때 각 군 간에 유의한 차이가 없음을 알 수 있었다 $(P>0.05)$

\section{iNOS 발현}

Fig. 4의 결과는 간조직을 균질화한 후 측정한 iNOS 발현을 측정한 결과이다. 이 결과 역시 Hepatitis-induced group에 비하여 나머지 실험군에서 통계적으로 유의한 차 이를 보이며 저하된 경향을 볼 수 있었으며 $(P<0.01)$ 특히 Sham 군에서는 iNOS 발현이 거의 이루어지지 않았음을 알 수 있었다. 사이토카인 분석 결과와 마찬가지로 $\mathrm{iNOS}$ 발현 역시 Pre-treatment 군과 post-treatment 군 사이에 유 의한 차이를 볼 수 없었다 $(P>0.05)$.

\section{고 찰}

고도화된 현대사회에서 잦은 음주문화와 스트레스로 인 
한 간질환 발병은 더욱 심화되어가고 있다. 통상 간염의 원인은 바이러스감염이 주요 원인이고 그 외 독극물, 지 방축척, 피로 등 다양한 원인에 의해서 발병하며 통상 6개월 이상 만성적인 염증상태가 지속되면 정상조직이 섬 유화되며 간기능이 사라지는 간경화로 진행하게 된다. 타 이레놀이라는 상표명으로 잘 알려진 아세트아미노펜은 전 세계적으로 사용되는 해열진통제이며 치료 용량의 범위가 협소한 잠재적인 내인성 간독소(intrinsic hepatoxin)이다. 성 인남성의 경우 아세트아미노펜을 $20 \mathrm{mg}$ 이상의 용량에서 황달과 함께 급속히 간부전이 이행한다고 알려져 있으 며 급성 간부전 이후 12 24시간 내에 간 효소(ALT, AST, ALT 등)의 수치가 상승한다고 알려져 있다(Ahn, 2006). 간세포의 손상을 분석하기 위하여 임상적으로 혈청 내의 $\mathrm{AST}, \mathrm{ALT}, \mathrm{ALP}$ 와 같은 효소의 활성도를 검사한다. A 혈청 에서의 AST, ALT 활성치 증가는 간세포의 파괴 및 장애 정도와 높은 상관성을 가지고 있으며 간에서 혈액에서 유 출되는 다른 효소에 비하여 예민하게 변동된다. ALP는 간 담관상피세포, 빼, 소장 등 여러 장기에 분포하는 효소이 며 역시 이 효소의 급속한 증가는 간손상을 의미한다. 본 연구에서는 성인에게서 급속한 간부전을 일으킨다고 알려 진 용량보다 높은 용량을 $\mathrm{SD}$ rat에게 투여하여 급속 간염 증을 일으켰다. 아세트아미노펜에 의한 간손상이 정상적 으로 이루어졌는지를 살피기 위하여 1 차 간기능검사를 실 시한 결과 아세트아미노펜 투여군에서 비정상적인 간기능 수치를 보임을 알 수 있었다(Table 1A). Rengyolone 투여 후 간기능 수치는 rengyolone 투여군과 비투여군 간의 확 연히 차이를 볼 수 있었으며 이는 rengyolone 투여가 만성 적인 간염을 호전시키는데 기여하였음을 알 수 있는 대목 이다(Table 1). Rengyolone의 경구투여가 간손상을 치료함 에 있어 염증발현저지에 대한 평가를 위하여 다음 연구를 진행하였다.

다양한 원인에 의하여 발생하는 염증반응은 그 원인과 반응하는 조직의 차이에 상관없이 유사한 변화를 보인다 고 알려져 있다. 이러한 유사한 염증과정을 공통적으로 매개하는 물질들로 염증성 사이토카인, NO, prostaglandin 등이 있다(Noh and Baek, 2009). 전염증성 사이토카인인 IL-1, TNF- $\alpha$, IL-6 등의 자극에 의해 iNOS의 과도한 활성 화로 대식세포, 간세포, 내피세포, 심근세포 등에서 장시 간 다량의 $\mathrm{NO}$ 를 생성하게 하는 것으로 알려져 있다. 생체 내 고농도의 NO 생성은 숙주세포의 파괴, 염증반응 유발 을 매개하여 조직을 상해한다(Tian et al., 2018). 따라서 NO 생성 저해제는 다양한 염증성 질환의 염증반응조절제로
서의 가능성에 대한 연구가 활발히 이루어지고 있다. 따 라서 Rengyolone의 염증발현 저지를 확인하기 위하여 염 증성 사이토카인 IL-6, TNF- $\alpha$ 과 그에 따르는 염증발현인 자 iNOS 발현을 살펴보았다(Fig. 2-4). 먼저 Fig. 2, 3의 혈 청 사이토카인 발현 결과를 보면 IL-6, TNF- $\alpha$ 의 발현이 Hepatitis-induced Group에 비교하여 Rengyolone 투여군들에 서 현저하게 낮은 농도를 보임을 알 수 있었다. 두 사이 토카인의 양상은 이 후 매개물질은 iNOS의 발현과도 관 계가 있었으며 그 결과는 Fig. 4에 보여주고 있다. 염증성 사이토카인 결과와 유사하게 $\mathrm{iNOS}$ 결과 역시 사이토카인 의 결과와 유사한 경향을 보임을 보이고 있으며 이는 사 이토카인의 농도의존적으로 Rengyolone 투여군에서 iNOS 단백발현이 저하하였음을 알 수 있었으며 이는 IL-6와 $\mathrm{TNF}-\alpha$ 에 의해 조절되는 이 단백발현의 기전을 고려하고 볼 때 합당하다고 볼 수 있다. 상세한 염증저하기전에 대 하여서 후 연구가 필요하며 아마도 rengyolone가 일련의 염증발현신호체계에서 저해제 역할을 했었을 것이라는 사 료된다. 하지만 Rengyolone의 간염증 발현 예방효과를 살 펴보기 위하여 진행한 pre 군(6주 투여)과 post 군(4주 투 여) 사이에 염증인자들 간에 통계학적으로 유의한 차이는 없었다.

본 연구에서 만성염증 동물모델에서 rengyolone 투여는 높아진 사이토카인의 농도를 저하시키며 관련염증인자의 발현을 저지함을 알 수 있었다. Rengyolone 투여가 염증저 하에 효과가 있음을 알 수 있었지만 염증 cascade 내에서 정확한 기전에 대한 분석은 향후 연구과제이다. 본 연구 결과는 미래에 rengyolone의 활용에 있어 중요한 자료로 활용될 수 있을 것이며 간염증과 관련된 후보약제로 사 용될 수 있을 것이라고 사료된다.

\section{ACKNOWLEDGEMENT}

This research was supported by the Korea Research Foundation (NRF-2017R1C1B5076959).

\section{CONFLICT OF INTEREST}

No potential conflict of interest relevant to this article was reported.

\section{REFERENCES}

Ahn BM. Acetaminophen-Induced Acute Liver Failure. J Korean Med Assoc. 2006. 49: 846-853. 
Brown GC. Mechanisms of inflammatory neuro degeneration: iNOS and NADPH oxidase. Biochem Soc Trans. 2008. 35: 1119-1121.

Debnath T, Kim DH, Lim BO. Natural products as a source of anti-inflammatory agents associated with inflammatory bowel disease. Molecules. 2013. 19;18: 7253-7270.

Gressner OA, Weiskirchen R, Gressner AM. Biomarkers of liver fibrosis: clinical translation of molecular pathogenesis or based on liver-dependent malfunction tests. Clin Chim Acta. 2007. 381: 107-113

Kanzler S, Teufel A, Galle PR. Liver function test to predict hepatic failure after liver resection--expensive and without clinical relevance. Zentralbl Chir. 2007. 132: 267-273.

Law AHY, Yang CLH, Lau ASY, Chan GCF. Antiviral effect of forsythoside A from Forsythia suspensa (Thunb.) Vahl fruit against influenza A virus through reduction of viral M1 protein. J Ethnopharmacol. 2017. 209: 236-247.

Lee JS, Kim HS, Lee YJ, Yong CS, Choi HG, Han GD, Kim JA, Lee JS. Hepatoprotective effect of Grifola frondosa water extract on carbon tetrachloride-induced liver injury in rats. Food Sci Biotechnol. 2008. 17: 203-207.

Lightsey JM, Rockey DC. Current concepts in ischemic hepatitis. Curr Opin Gastroenterol. 2017. 33: 158-163.

Mariotto S, Suzuki Y, Persichini T, Colasanti M, Suzuki H, Cantoni O. Cross-talk between NO and arachidonic acid in inflam- mation. Curr Med Chem. 2007. 14: 1940-1944.

Noh KH, Baek JH. Inhibitory effect of Taraxci herba extract on pro-inflammatory mediatory. J Korean Oriental Pediatrics. 2009. 23: 165-176.

Park HH, Jeong GM. Inhibitory effects of Maduryung (Aristolochiae Fructus) on alcohol, acetaminophen and galactosamine induced hepatitis in rats. The Journal of Korean Oriental Pediatrics. 2014. 9: 232-240.

Pérez-Gracia MT, Suay-García B, Mateos-Lindemann ML, MateosLindemann ML. Hepatitis E and pregnancy: current state. Rev Med Virol. 2017. 12: 54-60.

Qu H, Zhang Y, Wang Y, Li B, Sun W. Antioxidant and antibacterial activity of two compounds (forsythiaside and forsythin) isolated from Forsythia suspensa. J Pharm Pharmacol. 2008. 60: 261 -266 .

Thapa BR, Walia A. Liver function tests and their interpretation. Indian J Pediatr. 2017. 74: 663-671.

Tian Y, Abu-Sbeih H, Wang Y. Immune Checkpoint InhibitorsInduced Hepatitis. Adv Exp Med Biol. 2018. 995: 159-164.

https://doi.org/10.15616/BSL.2019.25.1.54

Cite this article as: Lee GH, Hyun KY, Kang YJ. Anti-inflammatory Modulating Effect of Rengyolone in Rat. Biomedical Science Letters. 2019. 25: 54-59. 